\title{
Microbial Decontamination of Fresh Produce (Strawberry) Using Washing Solutions
}

\author{
Naresh Shahi ${ }^{1}$, Byungjin Min ${ }^{1} \&$ Eunice A. Bonsi ${ }^{1}$ \\ ${ }^{1}$ Department of Food and Nutritional Sciences, Tuskegee University, Tuskegee, AL, 36088, United States \\ Correspondence: Byungjin Min, Department of Food and Nutritional Sciences, Tuskegee University, Tuskegee, \\ AL, 36088, United States. Tel:1-334-727-8393. E-mail: minbj@mytu.tuskegee.edu
}

Received: February 7, 2015 Accepted: March 11, 2015 Online Published: March 31, 2015

doi:10.5539/jfr.v4n3p128

URL: http://dx.doi.org/10.5539/jfr.v4n3p128

\begin{abstract}
This study was carried out to determine the effect of natural antimicrobial washing solutions against microbial growths on fresh produce specifically strawberries. Selected washing solutions used for strawberry washing, and treatments were sterile water (control), white vinegar (VI), crude lemon juice extract (LE), VI+Origanum oil (VIO), LE+Origanum oil (LEO), and VI+LE+Origanum oil (VILEO). From the preliminary study of antimicrobial activity of washing solutions in aqueous model system tested at 2, 5, 10, 15, 20 and 25 min against $S$. Typhimurium, washing time was determined as $5 \mathrm{~min}$ to be used for this study. After the washing, strawberries were stored at $4{ }^{\circ} \mathrm{C}$ for 5 days. Results showed that all natural washing solutions exhibited inhibitory effect against total aerobic bacteria, yeast and mold. On day 5, compared to the control, all washing solutions significantly reduced $S$. Typhimurium by $2.7 \mathrm{Log} C F U / g(P<0.05)$. Color results showed that samples color were slightly changed by washing with VIO and VILEO. However, there was no significant difference in total color change on strawberries compared to the control $(\mathrm{P}>0.05)$. Based on the results, it is indicated that the combination of vinegar with crude lemon juice extract and essential oil might be suitable as natural sanitizer for decontamination of fresh produce.
\end{abstract}

Keywords: antimicrobial, decontamination, washing solution, essential oil, strawberry

\section{Introduction}

Market trend along with fresh produce consumption continues to grow in recent years due to their health promoting capabilities (Jennylynd \& Tipvanna, 2010). It is suggested that daily consumption of fresh produce help to prevent degenerative and metabolic diseases such as cardiovascular disease, obesity and certain types of cancers (Rico, Martin-Diana, Barat, \& Barry-Ryan, 2007). Fresh produce can be a vehicle of microorganisms from farm to point of consumption (Schuele \& Snead, 2001); thus act as a source of foodborne illness (Beuchat, 1992). Fresh produce is vulnerable to potential microbial contamination at any points of the food value chain (WHO/FAO, 2006), if improper handling technique and storage occur during cultivation, harvesting, storage, transportation and distribution. Both pathogenic and/or deteriorative microorganisms may contaminate the product at any point of contact, increasing the risk of foodborne diseases (Diaz-Cinco, Acedo-Felix, \& Garcia-Galaz, 2005). It was reported that consumption increase, large scale production, distribution system, international trades etc. contributed to the increase in the outbreaks of human infections associated with fresh produce (Beuchat, 2002; Olaimat \& Holley, 2012). Fresh produce have been associated with outbreaks of foodborne diseases and food spoilage caused by bacteria, viruses, yeasts, molds and parasites in many countries (De Roever, 1999). Postharvest loss of fruit is a major challenge throughout the world. In the industrialized countries, it is estimated that loss can be up to $25 \%$ of harvested fruits. The situation is far more exacerbating in the developing countries, where postharvest loss can be over 50\% in some areas (Nunes, 2012). Fresh produce is decayed by pathogens during post harvesting and handling (Sharma et al., 2009). Household consumers are the final link in the food supply chain (Kagan, Aiello, \& Larson, 2002). Diverse bacterial communities can exist everywhere at home. Poor personal hygiene and unsanitary environment can result in cross-contamination of microorganisms in the kitchen (Sanita, 2006). According to World Health Organization (WHO, 2002), over 30 to $40 \%$ of the global populations are at risk for food borne diseases at home in every year. In the United States, from 1998 to 2008, up to $15 \%$ of food-related illnesses were from the home. In Europe, approximately one-third of foodborne diseases were associated with fresh produce at home (European Food Safety Authority, 2013). 
Various decontamination methods were developed and have been applied to improve safety of fresh produce. Industrial decontamination methods include synthetic chemicals and physical techniques such as chlorine, ozone, electrolyzed water, bromine, tri-sodium phosphate, iodine, irradiation, refrigeration, pulsed light, electrostatic sprays, and cold plasma (Goodburn \& Wallace, 2013). However, efficacy of decontamination is varied and none of these methods are able to ensure elimination of pathogens completely (Zivile, Irina, Kristina, Egle, \& Pranas, 2012). In addition, consumption of fresh produce without proper washing may be carcinogenic from chemical residues as well as by products (Beuchat, 2000). Synthetic chemicals and sophisticated technology such as chlorine dioxide, irradiation, and pulsed light may not be reliable sources for food safety and preservation at household level. Moreover, these techniques might be difficult to establish at large scale by government especially in developing countries because of lack of infrastructure and availability and accessibility of resources (FAO/APO, 2006).

Recently, researchers have focused more on alternative methods for the preservation and safety of fresh produce such as organic acids and essential oils which are generally recognized as safe (GRAS) to minimize foodborne pathogens (Akabas \& Olmez, 2007; Gunduz, Gonul, \& Karapinar, 2010). Studies found that origanum oil exhibited antimicrobial activity as well as antifungal properties (Calo et al., 2015; Manohar et al., 2001). It was reported that lemon juice and vinegars showed inhibitory activities against $C$. perfringens spore germination and outgrowth on reduced salt ( $\mathrm{Li}$ et al., 2012). Washing time and techniques are important considerations during decontamination of fresh produce (Goodburn \& Wallace, 2013). Nastou et al. (2012) reported that 2\% (v/v) acetic acid was shown to have some antimicrobial effect in most of the cases with immersion time of 5 or 10 min for fresh produce. Similarly, there was no significant reduction of $C$. jejuni in chicken wings after dipping in $2 \%$ acetic acids at $4{ }^{\circ} \mathrm{C}$, even with an increase in treatment time from 15 to $45 \mathrm{~min}$ (Zhao \& Doyle, 2006). Influences of micro-organisms by organic acids depend on several parameters including; reduction $\mathrm{pH}$, chain length, ratio of un-dissociated ions, cell physiology and metabolisms. It is assumed that weak organic acids are more effective than strong acids because they are lipophilic and easily penetrate plasma membrane and destroy the cell's genetic materials (Booth \& Kroll, 1989).

This study was carried out to identify and develop alternative washing solutions as sanitizer for microbial decontamination of strawberry using natural products such as vinegar, organic acids, lemon juice extract, essential oils, and their combinations. In addition, the study evaluated antimicrobial activities of natural washing solutions which contribute to the reduction of the risk of microbial contamination during refrigerated storage.

\section{Materials and Methods}

\subsection{Collection of Fresh Produce}

Fresh whole strawberries, fresh lemons and white vinegar were purchased from local grocery stores in Auburn, AL, USA and transported to the laboratory at Tuskegee University. The produce samples were chosen independently and randomly. All samples were analyzed within 24 hours of purchase while keeping them in their original storage condition. Origanum oil from Thymus capitatus was purchased from Sigma-Aldrich Company (St. Louis, MO, USA) and stored at $4{ }^{\circ} \mathrm{C}$.

\subsection{Preparation of Natural Antimicrobial Washing Solutions}

White vinegar solution (VI) was diluted with sterile water from $2 \%$ of stock solution and final concentration was $1 \%$. For crude lemon juice extract (LE), fresh lemons were aseptically washed with sterile water and cut with sterile knife and extracted by sterile juicer. Then crude extract was filtered by sterile Watman ${ }^{\circledR}$ filter paper (No. 1). The resultant clear solution was dissolved in sterile water to make lemon juice extract $(1: 1 \mathrm{v} / \mathrm{v})$. For combined washing solutions, $0.1 \mathrm{~mL}$ of origanum oil was dissolved in $99.9 \mathrm{~mL}$ of $1 \%$ white vinegar (VI) and lemon juice extract (LE) separately to obtain VIO and LEO, respectively. Similarly $0.1 \mathrm{~mL}$ of origanum oil was dissolved in $99.9 \mathrm{~mL}$ of combination of VI and LE to obtain VILEO. Sterile water was used as control and five treatments VI, LE, VIO, LEO, and VILEO were used as natural washing solutions in the present study. All washing solutions were prepared on the same day of produce wash, and solutions were stored in the refrigerator at $4{ }^{\circ} \mathrm{C}$ until used.

\section{$2.3 \mathrm{pH}$ Measurement of Washing Solutions}

The $\mathrm{pH}$ of washing solution was measured before and after washing of the sample with a $\mathrm{pH}$ meter (Denver Instrument, Model 215). Determination of $\mathrm{pH}$ was performed in triplicate at room temperature $\left(23^{\circ} \mathrm{C} \pm 2\right)$.

\subsection{Storage Study of Fresh Produce}

Fresh strawberries $(20 \mathrm{~g} \pm 0.2 \mathrm{~g})$ were used for storage study. Two sets of sample were prepared and two strawberries were used for each treatment. First set was used for the determination of total aerobic bacteria, yeast 
and mold counts. The second set was used for surface contamination with foodborne bacteria. Samples in the sterile sample bag were tested on day $0,1,3$, and 5 during the storage at $4{ }^{\circ} \mathrm{C}$ in the refrigerator. On the test day, samples were taken out of storage bag and microbiological analysis was performed.

\subsection{Analysis of Total Aerobic Bacteria, Yeast and Mold Counts}

Fresh sample was used to determine the total aerobic, yeasts and molds count. A $20 \mathrm{~g}$ of sample was dissolved and diluted $(1: 10 \mathrm{w} / \mathrm{v})$ in $0.1 \%$ buffered peptone water (BPW), homogenized by hand massage for 5 min and serially diluted with BPW. Diluted samples were plated on aerobic count plates and yeast and mold plates $3 \mathrm{M}^{\circledR}$ Petrifilm $\left(3 \mathrm{M}^{\circledR}\right.$ Microbiology, St. Paul, MN). $3 \mathrm{M}^{\circledR}$ Petrifilms were incubated at $37^{\circ} \mathrm{C}$ for 48 hours to determine total aerobic bacteria. Yeast and mold counts were determined after incubation at $25^{\circ} \mathrm{C}$ for 5 days. Aerobic plate counts, yeast and mold counts were determined according to the instructions by $3 \mathrm{M}^{\circledR}$ Microbiology.

\subsection{Bacterial Culture}

Salmonella Typhimurium (ATCC 51812) was obtained from School of Veterinary Medicine Allied Health at Tuskegee University. Stock cultures were transferred into Tryptic Soy Broth (Fulka analytical 22091, Sigma-Aldrich) and incubated at $37^{\circ} \mathrm{C}$ for $18 \mathrm{hrs}$. Cultures were streaked onto TSA plates and incubated at $37^{\circ} \mathrm{C}$ for $18 \pm 1 \mathrm{~h}$. Subsequently, single colony of bacteria was aseptically inoculated in $5 \mathrm{~mL}$ Tryptic Soy Broth (TSB) and incubated at $37^{\circ} \mathrm{C}$ for $18 \pm 1 \mathrm{~h}$ and $100 \mu \mathrm{L}$ of bacterial suspension was inoculated into $5 \mathrm{~mL}$ TSB for a subsequent $18 \pm 1 \mathrm{~h}$ incubation at $37^{\circ} \mathrm{C}$ to achieve a viable cell population of 8-9 Log CFU/mL. Salmonella was harvested by centrifugation at $5000 \mathrm{rpm}$ (Brofuge 22R, Heraeus Instruments, Inc., USA) for $5 \mathrm{~min}$ at $4{ }^{\circ} \mathrm{C}$. The supernatant was carefully discarded and pellet was washed and re-suspended in sterile peptone water and thoroughly mixed by vortexing. This centrifugation and washing procedure was repeated. The collected bacterial cells were diluted in peptone water for storage study. Defined numbers of inocula were determined by counting colonies from the $18 \mathrm{~h}$ cultured cells grown on TSA (spread $0.1 \mathrm{~mL}$ ) from each diluent by tenfold dilution. Correspondingly, optical density was also measured with the final concentration of 6-7 Log CFU/mL.

\subsection{Inoculation on Strawberry}

All the samples in sterile stainless steel tray were placed in sterile aluminum foil and subjected with UV treatment under the laminar flow hood for $25 \mathrm{~min}$ to eliminate the micro flora on strawberries before artificial contamination. Sequentially, $10 \mu \mathrm{L} / \mathrm{g}$ of suspension of $S$. Typhimurium with final bacterial concentration 6-7 Log CFU/mL was inoculated separately on the outer surface of strawberries. The bacterial culture solution was spot-inoculated and spread around the surface using pipette tips to ensure homogeneous spread across the surface. Contaminated samples were co-incubated for $2 \mathrm{~h}$ at room temperature then stored at $4{ }^{\circ} \mathrm{C}$ for 5 days.

\subsection{Sample Treatment with Dipping/Shaking}

Contaminated samples were dipped in approximately $50 \mathrm{~mL}$ of natural antimicrobial washing solutions VI, LE, VIO, LEO, VILEO, SW (sterile water/control), and WO (without wash), respectively in sterile beakers at room temperature. The samples were continuously shaken for $5 \mathrm{~min}$ at room temperature using automatic shaker at 100 $\mathrm{rpm}$. Strawberries were fully immersed into each natural antimicrobial washing solution. All the samples were immediately drained by sterile metal filter and placed in a sterile filter paper under bio safety cabinet and allowed to dry. One set was analyzed immediately after washing (day 0 ) and the other sets were stored in sterile bags at $4{ }^{\circ} \mathrm{C}$ for up to 5 days. During the washing process $\mathrm{pH}$ of the solution was recorded.

\subsection{Retrieval of Bacteria from Artificially Contaminated Sample}

Hekton Enteric Agar (HEA) was used for selection of artificially contaminated samples with $S$. Typhimurium. Samples were homogenized and diluted $(1: 1 \mathrm{~W} / \mathrm{V})$ with $0.1 \%$ buffered peptone water, then homogenized by hand massage and kept for $60 \mathrm{~min}$ before retrieving $S$. Typhimurium $0.1 \mathrm{~mL}$ aliquot was then pipetted from each sample and spread onto HEA plates. Isolation and identification of contaminated $S$. Typhimurium were performed, based on color of the isolated colonies. The black centered with green background colonies on HEA plates were selected as inoculated $S$. Typhimurium from strawberries. Isolated colonies were also compared with $S$. Typhimurium cultured on HEA as control plates. Isolated colony was subjected to further analysis on $3 \mathrm{M} ®$ Salmonella express system as a confirmative test. Handling procedures for $3 \mathrm{M}^{\circledR}$ Salmonella express system was followed according to manufacturer's instructions.

\subsection{Color Measurement}

A Minolta Chroma Meter (Model CR-400 version 1.11, Konica Minolta, Japan) was used to measure color values of samples. The CIE L*, a*, and $b^{*}$ were used where $L^{*}$ represents lightness, and $a^{*}$ and $b^{*}$ represents redness and yellowness, respectively. The instrument was standardized using reference color before color measurement. 
Strawberry samples were placed in clean plastic bag and color values were measured from three different representative spots at before and after wash and on day 5. Total color difference (Delta E) was calculated using equation (Equation 1) and compared among treatments before and after washed and at day 5. All measurements were performed in triplicate at room temperature $\left(23^{\circ} \mathrm{C} \pm 2\right)$.

Delta $\mathrm{E}$ of the color was calculated by equation as follows:

$$
\Delta \mathrm{E}=\sqrt{\Delta L^{2}+\Delta a *^{2}+\Delta b^{* 2}} \quad \ldots \ldots
$$

(Equation 1)

Where: $\Delta \mathrm{L}^{2}=\mathrm{L}_{\text {(final) }}^{2} \mathrm{~L}_{\text {(initial), }}^{2} \Delta \mathrm{a}^{2}=\mathrm{a}_{\text {(final) }}^{2} \mathrm{a}_{\text {(initial), }}^{2} \Delta \mathrm{b}^{2}=\mathrm{b}_{\text {(final) }}^{2}-\mathrm{b}_{\text {(initial), }}^{2}$

\subsection{Statistical Analysis}

Two replicate trials were performed for each experiment. Each treatment was replicated. Data were analyzed by repeated measurement-analysis of variances (RM-ANOVA) using the general linear model procedure of the statistical system SAS 9.3 (SAS Inst., Cary, N.C., U.S.A.). Mean comparisons were calculated using Fisher's Protected Least Significant Difference. Plate count data was converted to logarithms scale prior to their statistical analyses. Level of significance of all tests was defined at $\mathrm{P}<0.05$.

\section{Results and Discussion}

\section{1 pH Determination of Washing Solutions}

The $\mathrm{pH}$ of the washing solutions before and after washing fresh strawberries remained the same for all treatments throughout the study period. However, the $\mathrm{pH}$ of the strawberries washed with sterile water decreased from 6.8 to 4.9. All washing solutions were in low acidic $\mathrm{pH}$ and it was ranged from 2.2 to 2.7. No reduction of $\mathrm{pH}$ in strawberry was observed throughout the storage period (Data was not included). Most common household sanitizers such as commercial vinegars (white vinegars, apple cider vinegars), and lemon juice reduced the aerobic bacteria without affecting the organoleptic quality (Vijayakumar \& Wolf-Hall, 2002). In the study, pH range of the washing solutions was between 2.2 and 2.7, indicating that most of the acids were present in un-dissociated form (Cunningham, O'Byrne, \& Oliver, 2009).

\subsection{Decontamination of Microorganisms in Strawberries by Washing Treatments}

The effect of dipping while shaking in different washing solutions at room temperature on the survival of total aerobic bacteria (TAB) is presented in Figure 1. Result was analyzed by comparing the effect of each treatment with storage day.

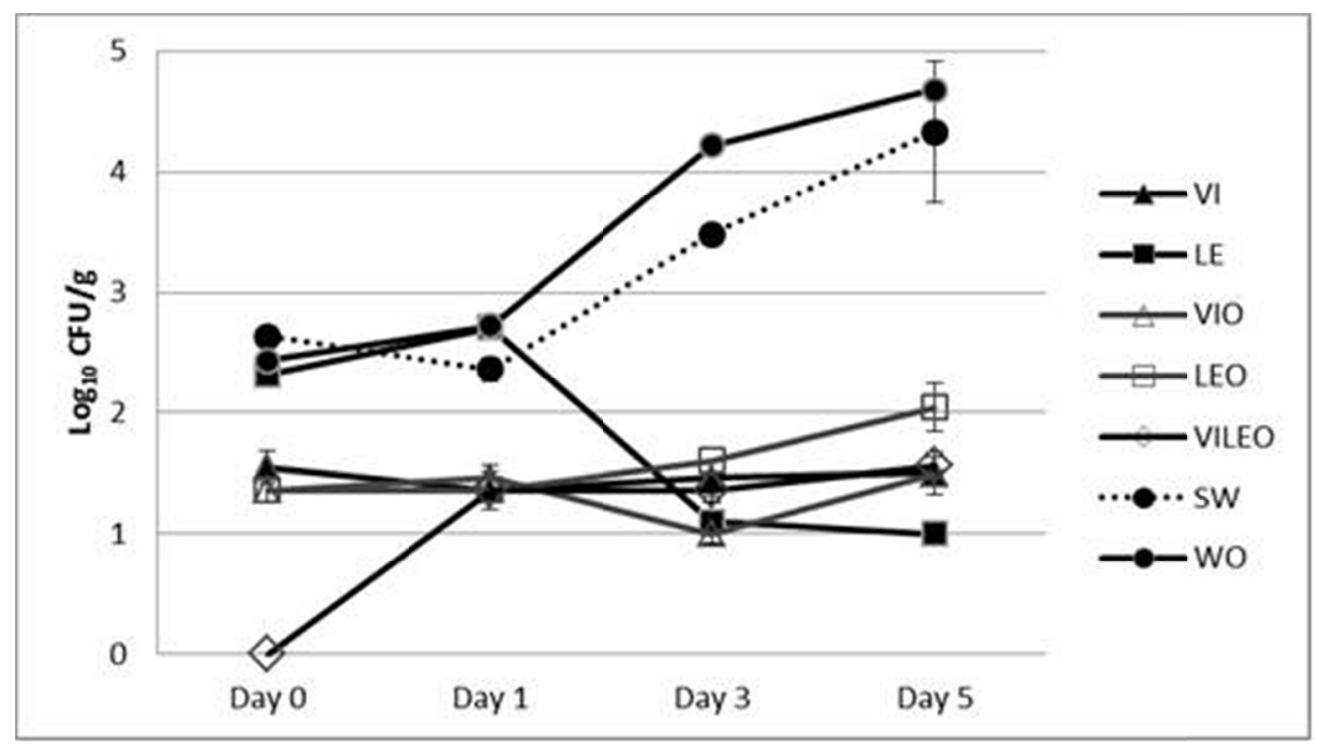

Figure 1. Effectiveness of washing solutions against total aerobic bacteria during storage at $4{ }^{\circ} \mathrm{C}$ on strawberries

(VI) White vinegar; (LE) Crude lemon juice extract; (VIO) VI+Origanum oil; (LEO) LE+Origanum oil; (VILEO) VI+LE+Origanum oil; (SW) Sterile water; (WO) Without wash 
At day 0 , initial population of TAB from unwashed (WO) and strawberries washed with sterile water (SW) were 2.4 and 2.6 Log CFU/g, respectively (Figure 1). Population of TAB on strawberries by WO and SW increased significantly on Day 3 and Day $5(\mathrm{P}<0.05)$. TAB counts on WO and SW were highest on day 5 with 4.7 and 4.4 Log CFU/g, respectively. On day 0 , bacterial reduction of TAB on strawberries washed with VI, LEO, VIO, and VILEO were 1.1, 0.3, 1.3, 1.3 and 2.6 respectively. Compared to the sterile water, on day 3 and day 5, TAB counts on strawberries washed by five washing treatments was reduced by 1.9 2.4 and 2.3 3.3 respectively. The results showed that vinegars and combination of washing solutions significantly reduced TAB as compared to control $(\mathrm{P}<0.05)$. Growth of yeast and mold were high in control samples throughout the storage time from 3.8 to $4.4 \mathrm{CFU} / \mathrm{g}$ as presented in Figure 2. Effectiveness of washing solutions at different storage days showed that population of yeasts and molds were significantly reduced by washing solutions. Washing solutions VI, LEO, and VILEO reduced yeast and mold counts on strawberries 3.7, 3.6, and $3.6 \mathrm{Log} \mathrm{CFU} / \mathrm{g}$, respectively as compared to control (Figure 2). Four washing solutions (VI, VIO, LEO, and VILEO) among the treatments also showed antifungal activities as well. The result of our study showed that the reduction of yeasts and molds counts on strawberries were significant $(\mathrm{P}<0.05)$. However, results also revealed that washing solution LE was not suitable to remove yeasts and molds from strawberry.

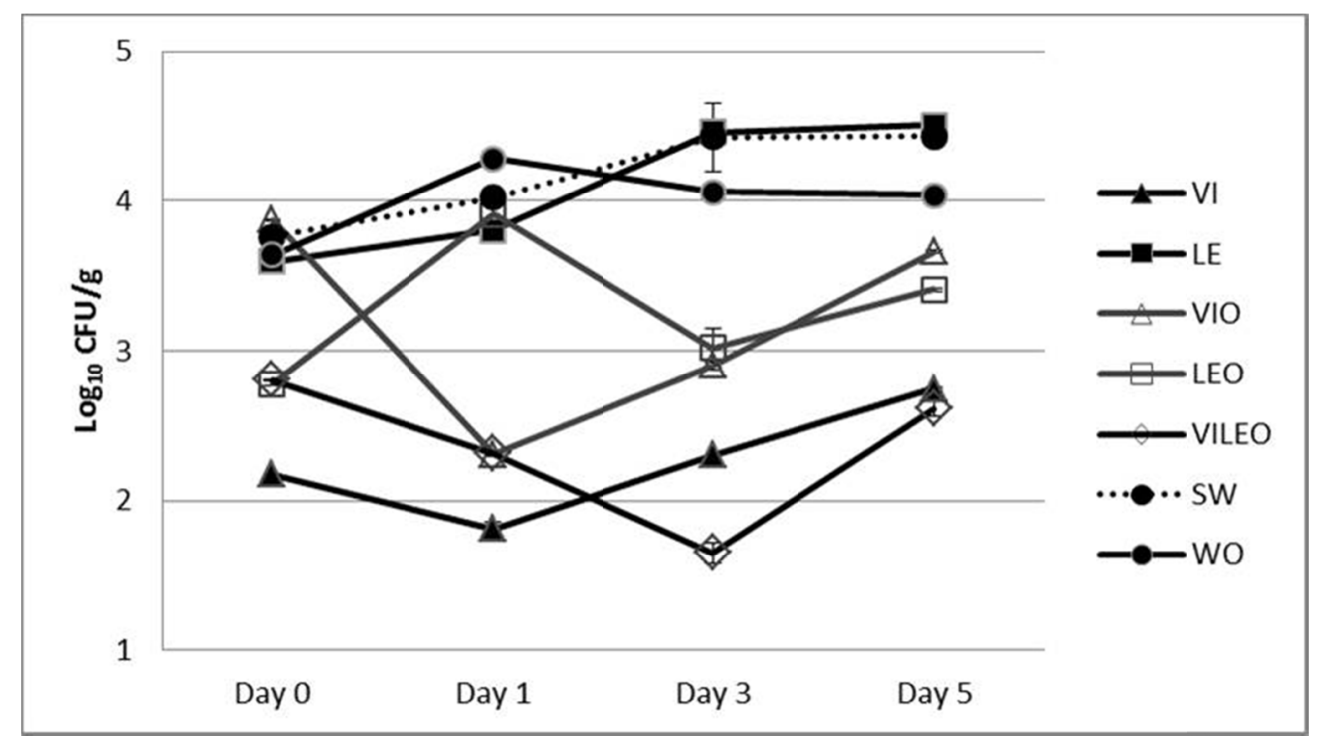

Figure 2. Effectiveness of washing solutions against fungal growth during storage at $4{ }^{\circ} \mathrm{C}$ in strawberries (VI) White vinegar; (LE) Crude lemon juice extract; (VIO) VI+Origanum oil; (LEO) LE+Origanum oil; (VILEO) VI+LE+Origanum oil; (SW) Sterile water; (WO) Without wash

It was reported that malted vinegar having concentration of 0.03 to $5 \%$ acetic acid largely reduced bacteria isolated from catfish after $15 \mathrm{~min}$ of dipping time; this result supported the concentration of commercial vinegars used in our study as an antimicrobial agents (Lingham, Lee, Besong, \& Ozbay, 2012). Chlorine is one of widely used sanitizers to prevent cross-contamination, but some studies showed that washing solution containing chlorine within the recommended range of 50-200 ppm cannot eliminate pathogens completely but can reduce 1 to $3 \mathrm{Log} \mathrm{CFU} / \mathrm{g}$ (Aruscavage, Lee, Miller, \& Lejeune, 2006). Therefore, various alternative natural sanitizing agents for fresh produce such as citric acid, lactic acid, ascorbic acid, peroxyacetic acid, and acidified sodium chlorite have been studied (Ruiz-Cruz, Acedo-Félix, \& Díaz-Cinco, 2007; Tajkarimi \& Ibrahim 2011, Altintas et al., 2013; Nastou et al., 2012). The method proposed in this study could be useful at house-hold level and it might be helpful to reducing washing time and sanitizing water especially under the situation where water resource is limited. This study also focused on alternative and reliable washing solution for fresh produce. Selected washing solutions, especially combination with origanum oil in this study significantly reduced viable count of bacteria and yeasts and molds from strawberry throughout the storage period. The active components present in essential oil have a broad spectrum of antimicrobial activity, against food-borne pathogens and spoilage bacteria (Gutierrez, Barry-Ryan, and Bourke (2009). The antimicrobial activity of essential oil is due to presence of hydrophilic functional group such as hydroxyl group of phenolic compound along with lipophilicity 
of essential oil (Dorman \& Deans, 2000). However, combination of treatments with origanum oil in this study showed less effect at day 0 , it might be due to the less dispersion and insufficient time of contact with microorganism to exhibit its antimicrobial activities at day 0 in strawberry. Nevertheless, results from this study showed that washing solutions VI, LE, VIO, LEO, and VILEO could be used as an alternative natural decontaminants washing solution for fresh produce at the house-hold level.

\subsection{Decontamination of Foodborne Pathogen}

Strawberries were artificially contaminated with $S$. Typhimurium and initial concentration of inoculum was 6 to $7 \mathrm{Log}$ CFU $/ \mathrm{ml}$. Bacterial populations on the surface of strawberry after the inoculum were 3.4 and $3.9 \log$ $\mathrm{CFU} / \mathrm{g}$ respectively. On day 0 , bacterial reductions after the washing by VI, LE, VIO, LEO and VILEO were 1.8, $1.9,2.1,3.4$ and 2.1 respectively. Compared to the sterile water, all washing solutions maintained antimicrobial activity through the storage time. Also, it was shown that all five washing treatments significantly reduced bacterial population by $2.7 \operatorname{logs}$ on day 5 as compared with SW wash and unwashed samples $(\mathrm{P}<0.05)$ as presented in Table 1. Particularly, compared to the control, $S$. Typhimurium by LEO wash on day $0,1,3$ and 5 was reduced by 3.4, 3.6, 3.2 and 2.7 respectively. Efficacies of washing solutions can differ with food samples and types of washing solution. In the present study, washing solutions were very effective to inhibit $S$. Typhimurium on strawberries (Table 1).

Table 1. Effectiveness of washing solutions during the storage against $S$. Typhimurium on strawberries

\begin{tabular}{lllll}
\hline Washing & \multicolumn{3}{c}{$\left(\log _{10} \mathrm{CFU} / \mathrm{g}\right)$} \\
Solution & Day 0 & Day 1 & Day 3 & Day 5 \\
\hline VI $^{1)}$ & 1.65 & 1.95 & $\mathrm{ND}^{2)}$ & $\mathrm{ND}$ \\
LE & 1.54 & 2.18 & $\mathrm{ND}$ & $\mathrm{ND}$ \\
VIO & 1.39 & 1.48 & 1.60 & $\mathrm{ND}$ \\
LEO & $\mathrm{ND}$ & $\mathrm{ND}$ & $\mathrm{ND}$ & $\mathrm{ND}$ \\
VILEO & 1.35 & 1.60 & 1.48 & $\mathrm{ND}$ \\
SW & 3.44 & 3.63 & 3.15 & 2.73 \\
WO & 3.87 & 3.64 & 3.17 & 2.66
\end{tabular}

${ }^{1)}$ (VI) White vinegar; (LE) Crude lemon juice extract; (VIO) VI+Origanum oil; (LEO) LE+Origanum oil; (VILEO) VI+LE+Origanum oil; (SW) Sterile water; (WO) Without wash.

${ }^{2)} \mathrm{ND}=$ Not Detected.

It was reported that selected house-hold vinegars with concentration of 2.5 and $5 \%$ acetic acids were effective in inhibition against L. monocytogenes, E. coli O157:H7, and S. Typhimurium however, only 5\% vinegar was effective against $S$. Typhimurium (Yang, Kendall, Medeiros, \& Sofos, 2009). Reduction of L. monocytogenes and pathogens after dipping/spraying or in combination with organic acid solutions has been reported in several studies (Akbas \& Olmez, 2007; Nastou et al., 2012). This study investigated the efficacy of dipping/shaking at room temperature with different natural washing solutions containing organic acids in combination with origanum oil and how these solutions reduced micro-organisms in the fresh produce under examination. Findings indicated that concentration of washing solution and selection of applied method can play an important role in effectiveness of reducing power against the microbial growths in strawberries. Natural substances exhibited the antimicrobial activities alone and sometime efficacy of the antimicrobial substances increased when combined with other substances. Fresh produce such as tomato and iceberg lettuce dipped in origanum oil solution at concentration of $15,25,40,75$, and $100 \mathrm{ppm}$ significantly reduced the $S$. Typhimurium, and natural flora by 2.8 $\mathrm{CFU} / \mathrm{g}$ at $75 \mathrm{ppm}$ (Gunduz, Gonul, \& Karapinar, 2010). Shredded lettuce with commercial vinegar containing $5 \%$ acetic acid (pH 3.0) for $5 \mathrm{~min}$ reduced E. coli $\mathrm{O} 157: \mathrm{H} 7$ and $S$. Typhimurium by 5 logs population at $25{ }^{\circ} \mathrm{C}$ (Chang \& Fang, 2007). It showed that $100 \mathrm{ppm}$ oregano oil reduced $S$. Typhimurium by $2.8 \mathrm{CFU} / \mathrm{g}$ (Gunduz et al., 2010). Findings in this study also demonstrated that crude lemon juice extract with concentration of $50 \%$ alone and in combination with origanum oil or vinegar significantly reduced $S$. Typhimurium. Organic compounds such as acetic acid, lactic acid and benzoic acid have antimicrobial effect; these compounds may disrupt microbial cell membrane or cell macromolecules or interfere with nutrient transport and energy 
metabolism, causing bactericidal effect (Rick, 2003). It is also reported that weak organic acids are more inhibitory activity than strong acid because they have lipophilic and penetrate plasma membrane and acidify the interior cell organelles (Booth \& Kroll, 1989). However, lemon juice was not effective for yeast and mold in strawberries used in this study. Yeasts and molds are more resistant at lower $\mathrm{pH}$ as compared to bacteria (Betts, 2013). Prior study reported that origanum essential oil has no antibacterial effect against tested human pathogenic bacteria but has antifungal activities against anthracbose-causing fungal plant pathogens in strawberry (Wedge, Mincsovics, Tabanca, \& Altintas, 2013). However, this study found that washing treatments were effective in inhibition for both pathogenic bacteria and fungi. Combination of treatments can be more effective towards tested organisms in some cases. Studies showed that combination of vinegar and lemon juice (1:1) reduced the $\log$ counts of 6.0 to 5.7 of viable $S$. Typhimurium and reduced to undetectable level when treatment was applied up to 30 min (Sengun \& Karapinar, 2004). Similarly, other studies found that combination of $2 \%$ organic acids (malic, lactic and citric acids) and ultrasound of $40 \mathrm{kHz}$ reduced number of $E$. coli O157:H7, L. monocytogenes and S. Typhimurium on lettuce leaves by 3.2-2.3 Log CFU/g (Sagong et al., 2011). In another study, combination of alkaline electrolyte water and $1 \%$ acetic acid reduced $L$. monocytogenes and $E$. coli O157:H7 by 4 Log CFU/g on shredded carrots (Rahman at al., 2011). Combination of organic acids (citric acid and ascorbic acids) reduced internalized $E$. coli and L. monocytogenes on lettuce by more than $3 \mathrm{Log} \mathrm{CFU} / \mathrm{g}$ (Olmez \& Temur, 2010). This study indicated that natural antimicrobial agents and their combinations can be an effective alternative washing solution. In addition to the application of sanitizing agents on food systems, it can be applied in kitchen environments. Several parameters are important to reduce the contamination of fresh produce at house hold level such as washing temperature, agitation, immersion time, concentration of treatments and biocidal agents.

\subsection{Color Analysis}

Fresh strawberries showed some variation in color values during storage. There was a slight change in $\Delta \mathrm{E}$ values in strawberries during storage. However, there was no significant difference compared with control $(\mathrm{P}>0.05)$ as presented in Table 2. Similarly, there were no significant differences in $L^{*}$ values $(\mathrm{P}>0.05)$ of strawberries among the treatments during the storage except VLO sample which was slightly darker (Table 3).

Table 2. Color changes $(\Delta \mathbf{E})$ of strawberries before, after washing and at day 5

\begin{tabular}{llll}
\hline Washing & \multicolumn{3}{c}{ Color Changes } \\
Solution & $\Delta \mathrm{E}_{\mathrm{BA}}{ }^{3)}$ & $\Delta \mathrm{E}_{\mathrm{B} 5}$ & $\Delta \mathrm{E}_{\mathrm{A} 5}$ \\
\hline $\mathrm{VI}^{1)}$ & $6.4 \pm 2.1^{\mathrm{a} 2)}$ & $8.9 \pm 2.5^{\mathrm{a}}$ & $6.5 \pm 1.6^{\mathrm{ab}}$ \\
$\mathrm{LE}$ & $6.4 \pm 2.1^{\mathrm{a}}$ & $7.9 \pm 2.5^{\mathrm{a}}$ & $4.9 \pm 1.6^{\mathrm{ab}}$ \\
VIO & $6.6 \pm 2.1^{\mathrm{a}}$ & $6.7 \pm 2.5^{\mathrm{a}}$ & $4.3 \pm 1.6^{\mathrm{b}}$ \\
LEO & $6.2 \pm 2.1^{\mathrm{a}}$ & $6.8 \pm 2.5^{\mathrm{a}}$ & $9.6 \pm 1.6^{\mathrm{a}}$ \\
VILEO & $10.8 \pm 2.1^{\mathrm{a}}$ & $8.8 \pm 2.5^{\mathrm{a}}$ & $8.8 \pm 1.6^{\mathrm{ab}}$ \\
S/W & $8.1 \pm 2.1^{\mathrm{a}}$ & $7.9 \pm 2.5^{\mathrm{a}}$ & $4.7 \pm 1.6^{\mathrm{b}}$ \\
W/O & $7.1 \pm 2.1^{\mathrm{a}}$ & $5.3 \pm 2.5^{\mathrm{a}}$ & $5.4 \pm 1.6^{\mathrm{ab}}$ \\
\hline
\end{tabular}

${ }^{1)}$ (VI) White vinegar; (LE) Crude lemon juice extract; (VIO) VI+Origanum oil; (LEO) LE+Origanum oil; (VILEO) VI+LE+Origanum oil; (SW) Sterile water; (WO) Without wash.

${ }^{2) \text { a-d }}$ Means \pm Standard Error within a same column followed by same superscript letters are not different $(\mathrm{P}>0.05)$.

${ }^{3)} \Delta \mathbf{E}_{\mathbf{B A}=}$ Changes in color between before and after washed; $\Delta \mathbf{E}_{\mathbf{B} 5=}$ Changes in color between before washed and after 5 days; $\Delta \mathbf{E}_{\mathbf{A} 5=}$ Changes in color between after washed and after 5 days.

The CIE a* values were lower on treatments VO and VLO in strawberry samples after the wash (Table 3 ). It is assumed that natural sanitizers might be helpful to extend the shelf-life of fresh produce without affecting the color. Natural color of strawberries may vary by different factors such as cultivar, cultivation condition, harvesting time and etc. However, color serves a useful criterion of quality and indication of various types of deteriorative effect in fresh produce. The change in delta $\mathrm{E}, \mathrm{L}^{*}, \mathrm{a}^{*}$ and $\mathrm{b}^{*}$ values indicated slight change in color before and after washing with solutions and during storage. It is indicated that present decontamination study is 
more suitable to preserve the color of fresh produce than physical methods. However, the right combination among fresh-cut and antimicrobial activity of essential oils must be anticipated to optimize the use of essential oils as natural additive for fresh- cut produce to meet consumer's requirements (Ayala-Zavala, Gonzalez-Aguilar, \& Del-Toro-Sanchez, 2009).

Table 3. Color values in strawberries before, after washed and at the end of storage day 5

\begin{tabular}{llllllllll}
\hline & \multicolumn{3}{c}{ Before Wash } & \multicolumn{3}{c}{ After Wash } & \multicolumn{3}{l}{ Day 5} \\
& $\mathrm{~L}^{*}$ & $\mathrm{a}^{*}$ & $\mathrm{~b}^{*}$ & $\mathrm{~L}^{*}$ & $\mathrm{a}^{*}$ & $\mathrm{~b}^{*}$ & $\mathrm{~L}^{*}$ & $\mathrm{a}^{*}$ & $\mathrm{~b}^{*}$ \\
\hline VI $^{1)}$ & $43.5 \pm 1.9^{\mathrm{a} 2}$ & $21.5 \pm 2.2^{\mathrm{a}}$ & $7.8 \pm 1.4^{\mathrm{a}}$ & $38.6 \pm 2.0^{\mathrm{ab}}$ & $19.0 \pm 1.6^{\mathrm{ab}}$ & $7.0 \pm 1.0^{\mathrm{ab}}$ & $39.3 \pm 2.0^{\mathrm{a}}$ & $18.2 \pm 2.9^{\mathrm{a}}$ & $6.2 \pm 1.3^{\mathrm{a}}$ \\
LE & $42.6 \pm 1.9^{\mathrm{a}}$ & $20.3 \pm 2.2^{\mathrm{a}}$ & $8.3 \pm 1.4^{\mathrm{a}}$ & $43.9 \pm 2.0^{\mathrm{a}}$ & $23.4 \pm 1.6^{\mathrm{a}}$ & $9.8 \pm 1.0^{\mathrm{a}}$ & $43.2 \pm 2.0^{\mathrm{a}}$ & $20.0 \pm 2.9^{\mathrm{a}}$ & $7.8 \pm 1.3^{\mathrm{a}}$ \\
VIO & $44.6 \pm 1.9^{\mathrm{a}}$ & $20.7 \pm 2.2^{\mathrm{a}}$ & $9.0 \pm 1.4^{\mathrm{a}}$ & $40.8 \pm 2.0^{\mathrm{ab}}$ & $18.0 \pm 1.6^{\mathrm{b}}$ & $6.5 \pm 1.0^{\mathrm{b}}$ & $40.2 \pm 2.0^{\mathrm{a}}$ & $17.0 \pm 2.9^{\mathrm{a}}$ & $7.0 \pm 1.3^{\mathrm{a}}$ \\
LEO & $40.6 \pm 1.9^{\mathrm{a}}$ & $19.0 \pm 2.2^{\mathrm{a}}$ & $6.4 \pm 1.4^{\mathrm{a}}$ & $41.4 \pm 2.0^{\mathrm{ab}}$ & $22.0 \pm 1.6^{\mathrm{ab}}$ & $8.7 \pm 1.0^{\mathrm{ab}}$ & $40.9 \pm 2.0^{\mathrm{a}}$ & $24.5 \pm 2.9^{\mathrm{a}}$ & $7.8 \pm 1.3^{\mathrm{a}}$ \\
VILEO & $44.6 \pm 1.9^{\mathrm{a}}$ & $21.4 \pm 2.2^{\mathrm{a}}$ & $8.6 \pm 1.4^{\mathrm{a}}$ & $37.6 \pm 2.0^{\mathrm{b}}$ & $18.2 \pm 1.6^{\mathrm{b}}$ & $6.3 \pm 1.0^{\mathrm{b}}$ & $39.0 \pm 2.0^{\mathrm{a}}$ & $19.4 \pm 2.9^{\mathrm{a}}$ & $7.6 \pm 1.3^{\mathrm{a}}$ \\
SW & $43.1 \pm 1.9^{\mathrm{a}}$ & $19.1 \pm 2.2^{\mathrm{a}}$ & $9.1 \pm 1.4^{\mathrm{a}}$ & $42.4 \pm 2.0^{\mathrm{ab}}$ & $23.5 \pm 1.6^{\mathrm{a}}$ & $8.9 \pm 1.0^{\mathrm{ab}}$ & $42.3 \pm 2.0^{\mathrm{a}}$ & $22.9 \pm 2.9^{\mathrm{a}}$ & $8.6 \pm 1.3^{\mathrm{a}}$ \\
WO & $43.1 \pm 1.9^{\mathrm{a}}$ & $16.7 \pm 2.2^{\mathrm{a}}$ & $7.1 \pm 1.4^{\mathrm{a}}$ & $40.9 \pm 2.0^{\mathrm{ab}}$ & $17.0 \pm 1.6^{\mathrm{b}}$ & $6.1 \pm 1.0^{\mathrm{b}}$ & $39.9 \pm 2.0^{\mathrm{a}}$ & $17.4 \pm 2.9^{\mathrm{a}}$ & $6.7 \pm 1.3^{\mathrm{a}}$ \\
\hline
\end{tabular}

1)(VI) White vinegar; (LE) Crude lemon juice extract; (VIO) VI+Origanum oil; (LEO) LE+Origanum oil;

(VILEO) VI+LE+Origanum oil; (SW) Sterile water; (WO) Without wash.

${ }^{2)}$ a-b Means \pm SE within a same column followed by same letters are not significantly different $(\mathrm{P}>0.05)$.

\section{Conclusion}

Based on the results, it is concluded that natural antimicrobial washing solutions were effective to inhibit foodborne pathogenic bacteria, yeasts and molds in strawberries. Therefore, it is suggested that natural washing solution has potential to be used as a house-hold washing solution for safety of fresh produce. It is recommended that further study in various washing temperature and sensory tests might be helpful to maximize inhibition effect on various foods and to determine the impact of washing solutions on consumer's organoleptic sensitivities and acceptability.

\section{Acknowledgements}

Authors would like to acknowledge Feed the Future Nutrition Innovation Lab/USAID/Tufts University (Award \# 39-22091289-78110) for funding, which provided us this opportunity, an invaluable contribution to the success of this study. Authors would also like to recognize George Washington Carver Agricultural Experiment Station, Tuskegee University, and Nepali Technical Assistance Group (NTAG) for their support during the process.

\section{References}

Akbas, H., \& Olmez, M. Y. (2007). Inactivation of Escherichia coli and Listeria monocytogenes on iceberg lettuce by dip wadh tratments with organic acids. The socity of Applied Microbiology, Letter to Applied Microbiology, 44, 619-624. http://dx.doi.org/10.1111/j.1472-765x.2007.02127.x

Altintas, A., Tabanca, N., Tyihak, E., Ott, P. G., Móriczm, A. M., Mincsovics, E., \& Widge, D. E. (2013). Characterization of volatile constituents from origanum onites and their antifungal and antibacterial activity. Journal of AOAC International, 96(6), 1200-1208. http://dx.doi.org/10.5740/jaoacint.sgealtintas

Amoah, S., Albano, E. E., \& Kobina, L. (2012). Application of antagonistic microorganisms for the control of postharvest decay in fruits and vegetables. International Journal of Advanced Biological Research, 2(1), $1-8$.

Aruscavage, D., Lee, K., Miller, S., \& Lejeune, J. T. (2006). Interaction affecting the proliferation and control of human pathogens on edible plants. Journal of Food Science, 71, 89-99. http://dx.doi.org/10.1111/j.1750-3841.2006.00157.x

Ayala-Zavala, J. F., Gonzalez-Aguilar, G. A., \& Del-Toro-Sanchez, L. (2009). Enhancing safety and aroma appealing of fresh-cut fruits and vegetables using the antimicrobial and aromatic power of essential oils. Journal of Food Science, 74(7). http://dx.doi.org/10.1111/j.1750-3841.2009.01294.x 
Betts, R. (2013). Microbial update: Yeasts and moulds. International Food Hygiene, 24(4), 10-11.

Beuchat, L. R. (2002). Ecological factors influencing survival and growth of human pathogens on rawfruits and vegetables. Microbes Infect, 4, 413-423. http://dx.doi.org/10.1016/s1286-4579(02)01555-1

Beuchat, L. R. (2000). Use of sanitizers in raw fruit and vegetable processing. In S. M. Alzamora, M. S. Tapia, \& A. López-Malo (Eds.), Minimally processed fruits and vegetables (pp. 63-77). Gaithersburg, MD, USA: Aspen Publishers, Inc. http://dx.doi.org/10.1007/978-1-4615-2393-2

Beuchat, L. R. (1992). Shelf stability and safety of fresh produce as influenced by sanitation and disinfection. Journal of food protection, 10(55), 808-814.

Booth, I. R., \& Kroll, R. G. (1989). Mechanisms events occurring in this region will not be expected of action of food preservation procedures, the preservation of and may well be reversed as the interface is crossed. In G.W. Gould (Ed.), Foods By Low pH (pp. 119-160) London, New York: Elsevier.

Calo, J. R., Crandall, P. G., O'Bryan, C. A., \& Ricke, S. C. (2015). Essential oils as antimicrobials in food systems - a review. Food Control, 54, 111-119. http://dx.doi.org/10.1016/j.foodcont.2014.12.040

Chang, J. M., \& Fang, T. J. (2007). Survival of E. Coli O157:H7 and Salmonella enterica serovars Typhimurium in iceberg lettuce and the antimicrobial effect of rice vinegar against E. coli O157:H7. Food Microbiology, 24, 745-751. http://dx.doi.org/10.1016/j.fm.2007.03.005

Cunningham, E., O’Byrne, C., \& Oliver, J. D. (2009). Effect of weak acids on Listeria monocytogenes survival: Evidence for a viable but non-culturable state in response to low pH. Food Control, 20(12), 1141-1144. http://dx.doi.org/10.1016/j.foodcont.2009.03.005

De Roever, C. (1999). Microbiological safety evaluations and recommendations on fresh produce food. Food Control, 9, 321-347. http://dx.doi.org/10.1016/s0956-7135(98)00022-x

Diaz-Cinco, M. E., Acedo-Flix, E., \& Garcia-Galaz, A. (2005). Principals microorganisms patogenous y de deterioro. Nuevas technologies de conservation de productos vegetables frescos cortados (pp. 216-240). CIAD, A.C. Sonora, Mexico.

Dorman, H. J. D., \& Deans, S. G. (2000). Antimicrobial agents from plants: antibacterial activity of plant volatile oils. J. Appl. Microbiol, 88, 308-316. http://dx.doi.org/10.1046/j.1365-2672.2000.00969.x

EFSA. European Food Safety Authority, European Centre for Disease Prevention and Control. (2013). The european union summary report on trends and sources of Zoonoses, zoonotic agents and food-borne outbreaks in 2011. EFSA J., 11, 3129.

FAO/APO. (2006). Postharvest Management offruits and vegetables in the Asia- pacific Region. In R. Rolle (Ed.), FAO/APO.

Goodburn, C., \& Wallace, C. A. (2013). The microbiological efficay of decontamination methodologies forfruits and vegetables: A review. Food Control, 32, 418-427. http://dx.doi.org/10.1016/j.foodcont.2012.12.012

Gunduz, G. T., Gonul, S. A., \& Karapinar, M. (2010). Efficacy of oregano oil in the inactivation of salmonella Typhimurium on lettuce. Food Control, 21, 513-517. http://dx.doi.org/10.1016/j.foodcont.2009.07.016

Gutierrez, J., Barry-Ryan, C., \& Bourke, P. (2009). Antimicrobial activity of plant essential oils using food model media: efficacy, synergistic potential and interaction with food components. Food Microbiol, 26, 142-150. http://dx.doi.org/10.1016/j.fm.2008.10.008

Jennylynd, B. J., \& Tipvanna, N. (2010). Processing of fresh-cut tropicalfruits and vegetables: A techniqual guide. Bangkon: RAP publication.

Kagan L. J., Aiello, A., \& Larson, E. (2002). The role of the home environment in the transmission of infectious diseases. Journal of Community Health., 27, 246-267. http://dx.doi.org/10.1023/a:1016378226861

Lingham, T., Lee, J. M., Besong, S., \& Ozbay, G. (2012). Antimicrobial activity of vinegar on bacterial species isolated from retails and local channel catfish (Ictalurus punctatus). J. food Process Technol, S11-001. http://dx.doi:10.4172/2157-7110.S11-001

Manohar, V., Ingram, C., Gray, J., Talpur, N. A., Echard, B. W., Bagchi, D., \& Preuss, H. G. (2001). Antifungal activities of origanum oil against candida albicans. Molecular and Cellular Biochemistry, 228, 111-117. http://dx.doi.org/10.1023/a:1013311632207

Nastou, A., Rhoades, J., Smirniotis, P., Makri, I., Kontominas, M., \& Likotrafiti, E. (2012). Efficacy of household washing treatments for the control of Listeria monocytogenes on. International Journal of Food Microbiology, 159, 247-253. http://dx.doi.org/10.1016/j.ijfoodmicro.2012.09.003 
Nunes, C. A. (2012). Biological control of postharvest diseases of fruit. European Journal of Pathology, 133(1), 181-196. http://dx.doi.org/10.1007/s10658-011-9919-7

Olaimat, A. N., \& Holly, R. A. (2012). Factors influencing the microbial safety of fruits and vegetables: A review. Food Microbiology, 32, 1-19. http://dx.doi.org/10.1016/j.fm.2012.04.016

Olmez, H., \& Temur, S. D. (2010). Effects of different sanitizing treatments on biofilms and attachment of Escherichia coli and Listeria monocytogenes on green leaf lettuce. LWT - Food Science and Technology, 43, 968-970. http://dx.doi.org/10.1016/j.lwt.2010.02.005

Rahman, S. M. E., Jin, Y. G., \& Oh., D. H. (2011). Combination of treatment of alkaline electrolyzed water citric acid with mild heat to ensure microbial safety, shelf-life and sensory quality of shredded carrots. Food Microbiology, 28, 484-491. http://dx.doi.org/10.1016/j.fm.2010.10.006

Ricke, S. C. (2003). Perspectives on the use of organic acid and short chain fatty acid as antimicrobials. Poult. Sci., 82, 632-639. http://dx.doi.org/10.1093/ps/82.4.632

Rico, D., Martin-Diana, A. B., Barat, J. M., \& Barry-Ryan, C. (2007). Extending and Measuring the quality of fresh-cut fruits and vegetables: A review. Trends in Food and Technology, 18, 373-386. http://dx.doi.org/10.1016/j.tifs.2007.03.011

Ruiz-Cruz, S., Acedo-Félix, E., \& Díaz-Cinco, M. (2007). Efficacy of sanitizers in reducing Escherichia coli O157:H7, Salmonella spp. and Listeria monocytogenes populations on fresh-cut carrots. Food Control, 18, 1383-1390. http://dx.doi.org/10.1016/j.foodcont.2006.09.008

Sagong, H-G., Lee, S-Y., Chang, P-K., Heu, S., Ryu, S., Choi, Y-J., \& Kang, D-H. (2011). Combined effect of ultrasound and organic acids to reduce Escherichia coli O157:H7, Salmonella Typhimurium, and Listeria monocytogenes on organic fresh lettuce. International Journal of Food Microbiology, 145(1), 287-292. http://dx.doi.org/10.1016/j.ijfoodmicro.2011.01.010

Sanita, I. S. (2006). Safe food in domestic environment: goals and recommendations for surveillance and prevention of foodborne disease (in Italiany). Rome.

Schuele, B., \& Snead, J. (2001). From Farm to fork, critical control points for food safety. Journal of Nutriton in Recipe and Meme Development, 3(1), 3-27. http://dx.doi.org/10.1300/j071v03n02_02

Sengun, I. Y., \& Karapinar, M. (2004). Effectiveness of lemon juice, vinegar and their mixture in the elimination of Salmonella Typhimurium on carrots (Daucus carota L.). International Journal of Food Microbiology, 96, 301-305. http://dx.doi.org/10.1016/j.jifoodmicro.2004.04.010

Sharma, M., Ingram, D. T., Patel, J. R., Millner, P. D., Wang, X., Hull, A. E., \& Donnenberg, M. S. (2009). A Novel approach to investigate the uptake and internalization of Escherichia coli O157:H7 in spinach cultivated in soli and hydroponic medium. Journal of Food Protection, 72(7), 1513-1520.

Vijayakumar, C., \& Wolf-Hall, C. E. (2002). Evaluation of household sanitizers for reducing levels of Escherichia coli on iceberg lettuce. Journal of Food Protection, 65, 1646-1650.

Wedge, D. E., Mincsovics, E., Tabanca, N., \& Altintas, A. (2013). Characterization of volatile constituents from origanum onites and their antifungal and antibacterial activities. Journal of AOAC International, 96(6), 1200-1208. http://dx.doi.org/10.5740/jaoacint.sgealtintas

WHO. (2002). Global strategy for food safety.

WHO/FAO. (2006). Guidelines for the safe use of wastewater, excreta and grey water: Wastewater in agriculture. Geneva: WHO/FAO.

Zhao, T., \& Doyle, M. P. (2006). Reduction of Campylobacter jejuni on chicken wings by chemical treatments. Journal of Food Protection, 4, 762-767.

Zivile, L., Irina, B., Kristina, K. Egle P., \& Pranas, V. (2012). High-power pulsed light for microbial decontamination of some fruits and vegetables with different surfaces. Journal of Food, Agriculture \& Environment, 10 (3\&4), 162-16.

\section{Copyrights}

Copyright for this article is retained by the author(s), with first publication rights granted to the journal.

This is an open-access article distributed under the terms and conditions of the Creative Commons Attribution license (http://creativecommons.org/licenses/by/3.0/). 